\title{
At the Dawn of Applied DNA Nanotechnology
}

\author{
Veikko Linko ${ }^{1,2}$ iD \\ 1 Biohybrid Materials, Department of Bioproducts and Biosystems, Aalto University, P.O. Box 16100, \\ 00076 Aalto, Finland; veikko.linko@aalto.fi; Tel.: +358-45-673-9997 \\ 2 HYBER Center of Excellence, Department of Applied Physics, Aalto University, 00076 Aalto, Finland
}

Received: 19 January 2020; Accepted: 23 January 2020; Published: 3 February 2020

Deoxyribonucleic acid (DNA) serves not only as a genetic information carrier but also as an excellent material for programmable nanoscale assembly [1,2]. The research field dubbed DNA nanotechnology has evolved significantly from simple structural motifs [3] to the current enabled state with ever-expanding shape space [4]. There is an extensive choice of methods for designing custom, user-defined, and accurate DNA nanoarchitectures for a number of fascinating functions [5], with DNA origami [6-8] being the most commonly employed technique. The various experimental procedures have emerged hand in hand with design software development [9], and, currently, the most prominent classes of DNA structures are based on lattices [10], molecular canvases [11], or wireframe constructions [12,13]. Some design methods are fully automated [14], and, arguably, this kind of advancement would encourage researchers to adopt easily accessible state-of-the-art approaches for their own laboratory toolbox. Importantly, it has also been shown that the extreme subnanometer-level precision of these objects [15] may be connected to larger length scales without a trade-off between the accuracy and dimensions of the system [16-18]. Apart from that, the upgraded and scaled-up production of DNA structures based on cost-effective biotechnological mass production has, remarkably, knocked down the price of synthesis [19]. Together with static and more complex objects, dynamic and functional DNA structures are increasingly coming into view [20,21], thus opening a route for sophisticated device fabrication for implementations in, e.g., biomedicine [22-24], super-resolution imaging [25,26], optical and plasmonic devices [27-31], and robotics [32-34]. In other words, we are currently at the dawn of a new era, looking forward to the bright future of applied DNA nanotechnology.

This Special Issue of Molecules entitled "Emerging Trend in DNA Nanotechnology" covers some of the key topics and challenges on our way toward real-life applications of DNA nanostructures. Dr. Katherine E. Dunn (University of Edinburgh, UK) summarizes, in her article, the existing and upcoming trends using data from publications and patent applications as indicators of expanding activities in the field [35]. This illustrative and intriguing article emphasizes the great promise of DNA nanotechnology and introduces examples of start-ups and spin-offs, while the real breakthrough in commercialization is still to be achieved.

During the past decade, most publications in the field have presented new types of DNA objects along with novel techniques and practices for effortless fabrication. It could be argued that it was a decade of learning how to build structures, and it is foreseen that the next one will be an era of doing something with them, including the development of new functionalities. One substantial subfield toward this research direction is to combine DNA nanostructures with active proteins [36,37]. In an extensive review of this issue, Prof. Barbara Saccà and her co-workers (University Duisburg-Essen, Germany) describe and list techniques to modulate and manipulate the properties of enzymes with the help of DNA structures [38]. I believe this article will be extremely useful for many researchers working on hybrid DNA-protein structures.

In the experimental research section of this issue, Prof. Shin-ichiro M. Nomura (Tohoku University, Japan) and colleagues report a refolding process of DNA origami in water-in-oil droplets, thus providing interesting insights into the self-assembly processes taking place in micron-sized compartments [39]. 
In another fundamental study, Prof. Ilko Bald's group (University of Potsdam, Germany) demonstrates how amorphous carbon is formed on discrete DNA origami-templated silver and gold nanoparticle aggregates when exposed to laser light [40]. These results may help researchers to find ways to prevent undesired amorphous carbon formation on widely employed DNA-based surface-enhanced Raman scattering (SERS) substrates.

Finally, a research led by Dr. Adrian Keller (Paderborn University, Germany) shows that the age of short DNA strands forming DNA origami may affect the quality of origami folding and their stability, especially in harsh experimental conditions [41]. The work is a logical continuation of the previous studies in this topical field exploring the (often superstructure-dependent) stability of DNA nanostructures in various challenging conditions [42,43] involving low-magnesium buffers [44] and other biologically relevant media, e.g., an endonuclease-rich environment [45] and in vivo experimentation [46].

As an Academic Guest Editor of this Special Issue, I would like to express my thanks to all the authors for their valuable contributions. I would also like to thank the editorial staff of Molecules and the reviewers of the manuscripts for their efforts and precious time. I hope you will find this collection of articles beneficial and inspiring.

Conflicts of Interest: The author declares no conflict of interest.

\section{References}

1. Seeman, N.C.; Sleiman, H.F. DNA nanotechnology. Nat. Rev. Mater. 2018, 3, 17068. [CrossRef]

2. Bathe, M.; Rothemund, P.W.K. DNA nanotechnology: A foundation for programmable nanoscale materials. MRS Bull. 2017, 42, 882-888. [CrossRef]

3. Seeman, N.C. Nucleic acid junctions and lattices. J. Theor. Biol. 1982, 99, 237-247. [CrossRef]

4. Linko, V.; Dietz, H. The enabled state of DNA nanotechnology. Curr. Opin. Biotechnol. 2013, 24, 555-561. [CrossRef] [PubMed]

5. Hong, F.; Zhang, F.; Liu, Y.; Yan, H. DNA origami: Scaffolds for creating higher order structures. Chem. Rev. 2017, 117, 12584-12640. [CrossRef]

6. Rothemund, P.W.K. Folding DNA to create nanoscale shapes and patterns. Nature 2006, 440, 297-302. [CrossRef]

7. Douglas, S.M.; Dietz, H.; Liedl, T.; Högberg, B.; Graf, F.; Shih, W.M. Self-assembly of DNA into nanoscale three-dimensional shapes. Nature 2009, 459, 414-418. [CrossRef]

8. Wang, P.; Meyer, T.A.; Pan, V.; Dutta, P.K.; Ke, Y. The beauty and utility of DNA origami. Chem 2017, 2, 359-382. [CrossRef]

9. Nummelin, S.; Kommeri, J.; Kostiainen, M.A.; Linko, V. Evolution of structural DNA nanotechnology. Adv. Mater. 2018, 30, 1703721. [CrossRef]

10. Castro, C.E.; Kilchherr, F.; Kim, D.-N.; Shiao, E.L.; Wauer, T.; Wortmann, P.; Bathe, M.; Dietz, H. A primer to scaffolded DNA origami. Nat. Methods 2011, 8, 221-229. [CrossRef]

11. Ke, Y.; Ong, L.L.; Shih, W.M.; Yin, P. Three-dimensional structures self-assembled from DNA bricks. Science 2012, 338, 1177-1183. [CrossRef] [PubMed]

12. Benson, E.; Mohammed, A.; Gardell, J.; Masich, S.; Czeizler, E.; Orponen, P.; Högberg, B. DNA rendering of polyhedral meshes at the nanoscale. Nature 2015, 523, 441-444. [CrossRef] [PubMed]

13. Veneziano, R.; Ratanalert, S.; Zhang, K.; Zhang, F.; Yan, H.; Chiu, W.; Bathe, M. Designer nanoscale DNA assemblies programmed from the top down. Science 2016, 352, 1534. [CrossRef] [PubMed]

14. Linko, V.; Kostiainen, M.A. Automated design of DNA origami. Nat. Biotechnol. 2016, 34, 826-827. [CrossRef]

15. Funke, J.J; Dietz, H. Placing molecules with Bohr radius resolution using DNA origami. Nat. Nanotechnol. 2016, 11, 47-52. [CrossRef]

16. Wagenbauer, K.F.; Sigl, C.; Dietz, H. Gigadalton-scale shape-programmable DNA assemblies. Nature 2017, 552, 78-83. [CrossRef]

17. Ong, L.L.; Hanikel, N.; Yaghi, O.K.; Grun, C.; Strauss, M.T.; Bron, P.; Lai-Kee-Him, J.; Schueder, F.; Wang, B.; Wang, P.; et al. Programmable self-assembly of three-dimensional nanostructures from 10,000 unique components. Nature 2017, 552, 72-77. [CrossRef] 
18. Tikhomirov, G.; Petersen, P.; Qian, L. Fractal assembly of micrometre-scale DNA origami arrays with arbitrary patterns. Nature 2017, 552, 67-71. [CrossRef]

19. Praetorius, F.; Kick, B.; Behler, K.L.; Honemann, M.N.; Weuster-Botz, D.; Dietz, H. Biotechnological mass production of DNA origami. Nature 2017, 552, 84-87. [CrossRef]

20. Ijäs, H.; Nummelin, S.; Shen, B.; Kostiainen, M.A.; Linko, V. Dynamic DNA origami devices: From strand-displacement reactions to external-stimuli responsive systems. Int. J. Mol. Sci. 2018, 19, 2114. [CrossRef]

21. DeLuca, M.; Shi, Z.; Castro, C.E.; Arya, G. Dynamic DNA nanotechnology: Toward functional nanoscale devices. Nanoscale Horiz. 2020, 5. [CrossRef]

22. Linko, V.; Ora, A.; Kostiainen, M.A. DNA nanostructures as smart drug-delivery vehicles and molecular devices. Trends Biotechnol. 2015, 33, 586-594. [CrossRef] [PubMed]

23. Zhang, Y.; Tu, J.; Wang, D.; Zhu, H.; Maity, S.K.; Qu, X.; Bogaert, B.; Pei, H.; Zhang, H. Programmable and multifunctional DNA-based materials for biomedical applications. Adv. Mater. 2018, 30, 1703658. [CrossRef] [PubMed]

24. Bujold, K.E.; Lacroix, A.; Sleiman, H.F. DNA nanostructures at the interface with biology. Chem 2018, 4, 495-521. [CrossRef]

25. Jungmann, R.; Avendaño, M.S.; Woehrstein, J.B.; Dai, M.; Shih, W.M.; Yin, P. Multiplexed 3D cellular super-resolution imaging with DNA-PAINT and Exchange-PAINT. Nat. Methods 2014, 11,313-318. [CrossRef]

26. Graugnard, E.; Hughes, W.L.; Jungmann, R.; Kostiainen, M.A.; Linko, V. Nanometrology and super-resolution imaging with DNA. MRS Bull. 2017, 42, 951-959. [CrossRef]

27. Kuzyk, A.; Schreiber, R.; Fan, Z.; Pardatscher, G.; Roller, E.-M.; Högele, A.; Simmel, F.C.; Govorov, A.O.; Liedl, T. DNA-based self-assembly of chiral plasmonic nanostructures with tailored optical response. Nature 2012, 483, 311-314. [CrossRef]

28. Gopinath, A.; Miyazono, F.; Faraon, A.; Rothemund, P.W.K. Engineering and mapping nanocavity emission via precision placement of DNA origami. Nature 2016, 535, 401-405. [CrossRef]

29. Shen, B.; Linko, V.; Tapio, K.; Pikker, S.; Lemma, T.; Gopinath, A.; Gothelf, K.V.; Kostiainen, M.A.; Toppari, J.J. Plasmonic nanostructures through DNA-assisted lithography. Sci. Adv. 2018, 4, eaap8978. [CrossRef]

30. Kuzyk, A.; Jungmann, R.; Acuna, G.P.; Liu, N. DNA origami route for nanophotonics. ACS Photonics 2018, 5, 1151-1163. [CrossRef]

31. Shen, B.; Kostiainen, M.A.; Linko, V. DNA origami nanophotonics and plasmonics at interfaces. Langmuir 2018, 34, 14911-14920. [CrossRef] [PubMed]

32. Douglas, S.M.; Bachelet, I.; Church, G.M. A logic-gated nanorobot for targeted transport of molecular payloads. Science 2012, 335, 831-834. [CrossRef] [PubMed]

33. Thubagere, A.J.; Li, W.; Johnson, R.F.; Chen, Z.; Doroudi, S.; Lee, Y.L.; Izatt, G.; Wittman, S.; Srinivas, N.; Woods, D.; et al. A cargo-sorting DNA robot. Science 2017, 357, eaan6558. [CrossRef] [PubMed]

34. Kopperger, E.; List, J.; Madhira, S.; Rothfischer, F.; Lamb, D.C.; Simmel, F.C. A self-assembled nanoscale robotic arm controlled by electric fields. Science 2018, 359, 296-301. [CrossRef]

35. Dunn, K.E. The business of DNA nanotechnology: Commercialization of origami and other technologies. Molecules 2020, 25, 377. [CrossRef]

36. Niemeyer, C.M. Functional devices from DNA and proteins. Nano Today 2007, 2, 42-52. [CrossRef]

37. Linko, V.; Nummelin, S.; Aarnos, L.; Tapio, K.; Toppari, J.J.; Kostiainen, M.A. DNA-based enzyme reactors and systems. Nanomaterials 2016, 6, 139. [CrossRef]

38. Jaekel, A.; Stegemann, P.; Saccà, B. Manipulating enzymes properties with DNA nanostructures. Molecules 2019, 24, 3694. [CrossRef]

39. Watanabe, T.; Sato, Y.; Otaka, H.; Kawamata, I.; Murata, S.; Nomura, S.-I.M. DNA origami "quick" refolding inside of a micron-sized compartment. Molecules 2020, 25, 8. [CrossRef]

40. Heck, C.; Kanehira, Y.; Kneipp, J.; Bald, I. Amorphous carbon generation as a photocatalytic reaction on DNA-assembled gold and silver nanostructures. Molecules 2019, 24, 2324. [CrossRef]

41. Kielar, C.; Xin, Y.; Xu, X.; Zhu, S.; Gorin, N.; Grundmeier, G.; Möser, C.; Smith, D.M.; Keller, A. Effect of staple age on DNA origami nanostructure assembly and stability. Molecules 2019, 24, 2577. [CrossRef] [PubMed]

42. Ramakrishnan, S.; Ijäs, H.; Linko, V.; Keller, A. Structural stability of DNA origami nanostructures under application-specific conditions. Comput. Struct. Biotechnol. J. 2018, 16, 342-349. [CrossRef] [PubMed] 
43. Bila, H.; Kurinsikal, E.E.; Bastings, M.M.C. Engineering a stable future for DNA-origami as a biomaterial. Biomater. Sci. 2019, 7, 532-541. [CrossRef]

44. Kielar, C.; Xin, Y.; Shen, B.; Kostiainen, M.A.; Grundmeier, G.; Linko, V.; Keller, A. On the stability of DNA origami nanostructures in low-magnesium buffers. Angew. Chem. Int. Ed. 2018, 57, 9470-9474. [CrossRef]

45. Ramakrishnan, S.; Shen, B.; Kostiainen, M.A.; Grundmeier, G.; Keller, A.; Linko, V. Real-time observation of superstructure-dependent DNA origami digestion by DNase I using high-speed atomic force microscopy. ChemBioChem 2019, 20, 2818-2823. [CrossRef]

46. Surana, S.; Shenoy, A.R.; Krishnan, Y. Designing DNA nanodevices for compatibility with the immune system of higher organisms. Nat. Nanotechnol. 2015, 10, 741-747. [CrossRef]

(C) 2020 by the author. Licensee MDPI, Basel, Switzerland. This article is an open access article distributed under the terms and conditions of the Creative Commons Attribution (CC BY) license (http://creativecommons.org/licenses/by/4.0/). 